\title{
I'll spin a thread of my own: prefiguracija mita o vernoj Penelopi
}

\author{
Marija N. Gagić* \\ Univerzitet u Beogradu, Filološki fakultet
}

\author{
Ključne reči: \\ prefiguracija mita \\ Odiseja \\ Penelopa \\ intertekstualnost \\ feministička teorija \\ metafikcija
}

\begin{abstract}
Apstrakt
U svom romanu Penelopijada Margaret Atvud (Margaret Atwood) dekonstruiše patrijarhalne prakse ukorenjene u Homerovoj Odiseji kroz upotrebu i zloupotrebu ustaljenih mitoloških konvencija. Shodno tome, ovaj roman može se posmatrati kao reprezentativan primer postmodernističkog parodijskog dijaloga sa prošlošću. Okvir za izučavanje posthomerovskih modifikacija pružiće prvenstveno intertekstualne, strukturalističke, metafikcijske i feminističke perspektive. Intertekstualnim praksama i semiološkom redistribucijom korektivno se pristupa androcentričnim stavovima prisutnim u originalnom mitu. Povrh toga, mnogostrukost narativnih perspektiva postaje rodno obeležena kao ženska taktika za prekrajanje falogocentričnih sistema. Pasivnost i patnja gube status Penelopinih glavnih odlika usled njenog aktivnog odupiranja sopstvenoj viktimizaciji. Njenim sluškinjama se, kao prethodno nemim i marginalizovanim figurama omogućava da, sa hijerarhijski izjednačene pozicije, zahtevaju pravdu. U radu se takođe predlaže dodatno polazište - istoriografska metafikcija, po kojoj se Penelopino tkanje uzima kao simbol celokupnog ženskog stvaralaštva, čime se književnice pozivaju da aktivno doprinose književnom kanonu. (примьено: 8. марта 2021; прихваћено: 15. јула 2021)
\end{abstract}




\section{Uvod}

Linda Hačion (Linda Hutcheon) opisuje postmodernizam kao inicijativu koja „upotrebljava i zloupotrebljava, ustanovljava i zatim destabiliše konvencije na parodijski način, samosvesno ukazujući na sopstvene nerazdvojive paradokse i provizornosti, na sopstveno kritičko ili ironijsko ponovno čitanje umetnosti prošlosti“ (1996: 49). Margaret Atvud na sličan način pristupa mitološkoj građi u Odiseji, preciznije, priči o Odisejevoj vernoj supruzi Penelopi i njenih dvanaest sluškinja. Ovaj revizionistički poduhvat čini roman značajnim lokusom kritičkog i parodijskog dijaloga sa prošlošću, kojoj se okreće kako bi „dekonstruisao i rekonstruisao predstave žena nasleđene iz muške literature“ (Gilbert/Gubar, 1984: 75). Kao tekst sa dalekosežnim sociokulturnim uticajem, Odiseja promoviše izvesne stereotipe i društvena očekivanja, pogotovo kada se radi o ženskim likovima i njihovoj ulozi u bračnim, porodičnim i društvenim odnosima. U Uvodu Atvud iznosi nameru da Penelopi i sluškinjama omogući da ispričaju svoju stranu priče kako bi razjasnila nejasnoće u originalnom epu i odgovorila na dva ključna pitanja: „Šta je razlog vešanja sluškinja?“ i „Šta je to Penelopa zapravo smerala?“ (Atvud, 2005: 16). Dijegetički okvir homerovskog epa koji je nekada služio dogmatizaciji Penelope kao pasivne junakinje stoga podleže poststrukturalističkoj i feminističkoj rekontekstualizaciji.

Teorijski pravci poput parodijske intertekstualnosti, strukturalne lingvistike, feminističke kritike $i$ istoriografske metafikcije mogu pružiti adekvatan analitički okvir za tumačenje Penelopijade kao savremenog mita. Sva četiri metodološka pristupa služe kako bi se holistički obuhvatila građa romana i objasnile sociokulturne implikacije rekonstruisanja dominantnih istorijskih narativa.

Prvobitno definisan u teoriji Julije Kristeve (Julia Kristeva), a potom i Linde Hačion, pojam intertekstualnosti predstavlja plodonosan književni postupak koji otvara put za feminističku teoriju i njen kritički komentar na istoriju. Slično Kristevoj, Rolan Bart (Roland Barthes) koristi strukturalnu lingvistiku kako bi opisao mit kao podesno oruđe za ideološko izokretanje, ali i opisao mehanizam za njegovu prefiguraciju. Naime, proizvoljnost jezičkog znaka ukazuje na to da se postojećim ideološkim $i$ istorijskim diskursima mogu pripisati nove konotacije $i$ asocijacije kada se oni izmeste u novi, savremeni kontekst.

Centralni motiv u Penelopijadi zauzima Penelopino tkanje Laertovog pokrova kao lukave strategije kojom odvraća prosce i kupuje sebi vreme do Odisejevog povratka u Itaku. Ograničen prostor u kom je Penelopa prinuđena da reaguje može se objasniti istorijskim kontekstom i terminom oikos (grč. kuća, dom) koji u antičkom društvu označava privatnu sferu, omeđen prostor u kom žena obitava. Uprkos nefleksibilosti i rigidnosti Penelopinog položaja, ona uspeva da upravo tkanjem pretvori sebe u aktivnu delatnicu, po mudrosti, rečitosti i lukavstvu doraslu Odiseju.

Džasmin Ričards (Jasmine Richards) tumači Penelopino tkanje dvojako: kao čin otpora i alegoriju ženskog autorstva (2019: 125). Sa jedne strane, njeno tkanje zadobija emancipatorsku funkciju unutar ograničenog proscenijuma na koji je kao žena osuđena. Pokrov postaje ujedno i materijalna i narativna tapiserija koja će Penelopi omogućiti da sa sebe strgne etiketu pasivne žrtve. Sa druge strane, u širem, meta- 
fikcijskom kontekstu, Penelopijada daje komentar na ono što francuska poststrukturalistkinja Elen Siksu (Hélène Cixous) naziva l'ecriture feminine - žensko pisanje:

Trebalo bi da se žena ispiše: da žena piše o ženi i da privede ženu pismu, od koga su, na isti način kao i od svojih tela, one nasilno udaljene; iz istih pobuda, na osnovu istog zakona, sa istim smrtnim ciljem. Trebalo bi da žena iznese u tekst - kao i na svet, i u istoriju - svoj sopstveni pokret. Ne bi trebalo da prošlost ispisuje budućnost. (Siksu, 2010: 1)

Žensko pisanje kod Siksu postaje sredstvo otpora protiv muškog logocentrizma. Sukob muškog i ženskog jezičkog položaja može dovesti do „primarne stvaralačke anksioznosti“ (Richards, 2019: 128) koja obeshrabruje žene kada se radi o stvaralačkom poduhvatu. Razotkrivši poroznost ustaljenih konvencija i falogocentričnog diskursa koji potčinjava žene, Margaret Atvud svrstava Penelopu među plejadu „žena zarobljenih sa druge strane ogledala/teksta“ kojima autorka pomaže da iz tog ogledala izađu (Gilbert/Gubar, 1984: 15).

\section{Teorijski okvir: intertekstualna plodonosnost mita}

U svom uticajnom eseju Reč, dijalog, roman Julija Kristeva po prvi put definiše intertekstualnost, pozivajući se na svoje teorijske preteče - De Sosirovu (Ferdinand de Saussure) strukturalnu lingvistiku i Bahtinove (Mikhail Bakhtin) termine polifonije, dijalogizma i heteroglosije. Preuzimajući Bahtinov model „dijahronije koja se transformiše u sinhroniju“, ona opisuje književnu reč kao „preklapanje tekstualnih ravni“, odnosno, kao koordiniran dijalog između pisca, primaoca i sadašnjeg ili prošlog kulturnog konteksta (Kristeva, 1986: 36). Kristeva takođe iznosi ideju da se „svaki tekst gradi kao mozaik citata“ i da je „svaki tekst apsorpcija i transformacija drugog teksta“ (Kristeva u Lisowska, 2014: 21). Prema tome, svaki tekst predstavlja međusobno prožimanje i kolaborativnu interakciju sa drugim tekstom. Poetski jezik i mimeza stupaju u ,intraideološku debatu“ (Kristeva, 1984: 61). Kao takvi, oni su neraskidivi i mogu se koristiti kako bi se dovela u pitanje ideologija i razotkrile njene esencijalističke pretenzije. Dijaloška veza između prošlosti i sadašnjosti u postmodernizmu manifestuje se kroz želju da se, izmeštanjem iz svog prvobitnog konteksta, prošlost ponovo ispiše: „postmodernizam ističe svoju zavisnost svojom upotrebom kanona, ali otkriva svoju pobunu putem njihove ironijske zloupotrebe“ (Hačion, 1996: 218).

Teza o intertekstualnoj fluidnosti mitova može poslužiti i kao manifest savremenih feminističkih teorija. U okviru njih, homerovski motiv žene kao objekta koji se poseduje i razmenjuje može se denaturalizovati. Upravo to je ono što Penelopa najavljuje na samom početku romana. Paradoksalno, ona iz Hada kao bestelesno biće, „bez kostiju, bez usana, bez grudi“ (Atvud, 2005: 17) priča svoju verziju događaja. U kontekstu Penelopijade, reprodukcija mita negira postojanje apsolutizma kada se radi o transistorijskim istinama (Suzuki, 2007: 268), naročito kada su one epistemološki sagledane iz muške perspektive. Na sličan način, Marina Vorner (Ma- 
rina Warner) naglašava značaj kritičke prerade mitova - oslobađanja negativnih uporišta i učitavanja novih varijacija u mitološku građu, naročito kao kolektivne stvaralačke aktivnosti (Warner u Korkmaz, 2010: 22).

U svom delu Mitologije (Mythologies), Rolan Bart se takođe služi desosirovskim strukturalizmom kako bi kategorički predstavio mit kao semiološki sistem. Dok se formalne granice mita mogu jasno definisati, supstancijalne granice ne mogu se precizirati: „Svaki predmet može iz jednog zatvorenog, nemog postojanja da pređe u govorno stanje, otvoreno za priliku da ga usvoji društvo“ (Bart, 2013: 183). Izjava ovog tipa postulira mit kao potencijalno subverzivni medijum, što je zaključak koji Bart izvodi nakon revizionističkog pristupa De Sosirovoj strukturalnoj shemi.

Na semiotičkom planu, neophodno je najpre uspostaviti razliku između lingvističkog i mitološkog sistema. Trijadni odnos između označitelja (akustička slika), označenog (koncept) i znaka (asocijativna veza između označitelja i označenog) predstavlja formalnu osnovu strukturalne lingvistike. U sferi mita, ova podela poprima novu dimenziju i mit je sagledan kao semiološki sistem drugog stepena u kom znak sistema prvog stepena postaje polazište, označitelj u drugom. U Bartovoj terminologiji, označitelj se u sistemu prvog stepena naziva smisao, a u mitološkom sistemu postaje forma. Označeno ostaje okarakterisano kao pojam. Znak kao treći član koji se temelji na korelaciji prva dva postaje značenje (Bart, 2013: 190).

Svaki prelazak iz sfere smisla u sferu forme jeste regresivne prirode. Smisao postaje nekontigentan, prazan, siromašan, udaljen, značenjski potpuno degradiran: „Funkcija mita je da isprazni stvarno, on je, doslovno, neprestano oticanje, hemoragija, isparavanje, osetno odsustvo“ (Bart, 2013: 213). Označeno je, nasuprot tome, posve određeno i sadrži stabilno ugrađeno značenje. Kao takvi, forma i pojam su obrnuto srazmerni: „Kvalitativnom siromaštvu forme u koju je pohranjen tek jedan proređen smisao, odgovara bogatstvo pojma otvorenog prema čitavoj Istoriji, dok kvantitativnom obilju formi odgovara mali broj pojmova“ (Bart, 2013: 193).

Iz ovog poređenja jasno je da desosirovski sistem jezika u užem smislu ne podrazumeva istu dogmatičnost značenja kao mitološki sistem. Namećući se kao činjenično stanje, mit stoga poseduje „nametljvu, imperativnu, interpelacijsku narav“ i postaje „ukradeni i vraćeni govor“ (Bart, 2013: 196). Suštinski cilj mita jeste da naturalizuje istoriju: „mit je zadužen da jednu istorijsku intenciju utemelji u prirodi, jednu kontigentnost u večnosti“ (Bart, 2013: 213). Pošto služi naturalizaciji potencijalno opasnih koncepata, mit je i predatorska odrednica, potencijalno oružje u rukama esencijalističkih tvorevina (ovde patrijarhata):

[Mit] ukida složenost ljudskih činova, daje im jednostavnost suština, poništava svaku dijalektiku, svaki izlazak iz okvira neposredno vidljivog, on organizuje svet u kom nema protivrečnosti zato što nema dubine, svet rasprostrt u očiglednosti, on utemeljuje izvornu jasnoću: stvari izgledaju kao da same po sebi nešto znače. (Bart, 2013: 214) 
Najbolji otklon od ovog nametanja Bart vidi u stvaranju trećeg semiološkog lanca, daljoj mitologizaciji u kojoj novo polazište postaje značenje prvog mita: „Pošto mit krade jezik, zašto ne ukrasti mit?" (Bart, 2013: 206). Razotkrivajući njegovu naivnost, ovakva vrsta teorijskog angažovanja otvara put za demistifikaciju mita prvog stepena.

Penelopi kao označitelju u Homerovom mitu pridruženo je označeno u vidu arhetipske ženske figure anđela. Ona ,nema sopstvenu priču već pruža savete i utehu drugima, sluša, smeje se, saoseća se“ (Gilbert/Gubar, 1984: 21). U novoj verziji mita, ona kao autodijegetički narator odbija da sudeluje u sopstvenoj viktimizaciji i postaje Penelopa koja „laže, sumnja, kaje se“ (Vandamme, 2010: 32). Ako kao polazište uzmemo značenje prvobitnog mita i pridodamo mu ove nove asocijacije i konotacije, nastaje novi mit u kom Penelopa nije više obojena predstavama ženstvenosti kao odsustva glasa, već postaje emancipovani ženski subjekat unutar trećeg semiološkog lanca.

\section{Destabilizacija antičkih konvencija}

Oslanjanje na prošlost, uzvišen jezik, poštovanje klasne hijerarhije, moralna besprekornost epskih junaka i prisustvo natprirodnih pojava mogu se izdvojiti kao definišuće karakteristike epskog žanra. Odiseja nije izuzetak. Uprkos tome što se autorka eksplicitno poziva na građu polazišnog mita, celokupan roman prožima oglušavanje o svaku konvenciju koja bi se očekivala od epa. Atvud mitove vidi kao nepresušan i neuništiv izvor inspiracije, medijum koji može sebe iznova i iznova da obnavlja, menja ruho, preuzima nova značenja (Atwood u Howells, 2006: 5). Književni preobražaj Odiseje odgleda se u izmeštanju svih očekivanih motiva u savremeni okvir, čime se podrivaju utvrđena pravila i prilagođavaju novom kontekstu. Ovaj roman takođe predstavlja žanrovski pastiš koji slavi ućutkane ženske glasove (Massoura, 2017: 395): kombinaciju epopeje i lirskih žanrova poput ljubavne pesme, tužbalice, morske pesme, balade, idile, kao i dramskih formi sudske drame i predavanja iz antropologije (Jung, 2014: 41, 45). Gilbert i Gubar u ovakvom poduhvatu vide postizanje istinskog ženskog književnog autoriteta istovremenim prisvajanjem i subverzijom patrijarhalnih književnih standarda (1984: 73).

Celokupna građa romana može se tumačiti i kao anahronizam - sudar dvaju hronotopa, antičke prošlosti i savremenog trenutka. Penelopa se čitaocima obraća iz podzemnog sveta kako bi retroaktivno objasnila sve događaje koji su obeležili njen život. Navođenje ličnosti poput Adolfa Hitlera i Merilin Monro, savremenih koncepata poput video-snimka, berze i zanimanja poput magnata, filmske zvezde i reklamnog agenta na samom kraju romana dozvoljava nam da smestimo vreme radnje u savremeno zapadnjačko društvo. U jednom od primera metanarativnih postupaka u romanu, lik sudije izjavljuje: „Doba vašeg klijenta nije naše doba. Tada su norme ponašanja bile drugačije. [...] Takođe, ne želim da budem kriv za anahronizam“ (Atvud, 2005: 132).

Ovakva vrsta hronološkog nepodudaranja prisutna je i na planu jezičkog izraza. Jezik koji se koristi u epovima karakteriše uzvišenost izraza, formulaičan jezik, če- 
ste invokacije i obraćanja natprirodnim bićima, kao i upotreba hora kao dramskog sredstva. Za razliku od Odiseje, jezik u Penelopijadi je moderan, kolokvijalan, ličan i na momente prošaran ekspletivima.

Pojednostavljenost jezika takođe signalizira ukidanje klasnih razlika između Penelope i njenih sluškinja. Suzan Jung (Susanne Jung) sagleda Penelopijadu kao „strukturalno i hermeutički višeglasnu“ - polilog u kom se dve paralelne narativne niti stapaju u jednu (2014: 45). Antički hor u vidu ubijenih sluškinja javlja se kao sporedna nit koja podupire glavnu radnju pripovedanu u prvom licu. Zapostavljene sluškinje javljaju se iz zagrobnog života i u pevanim interludima, sa pozicije epistemološke privilegovanosti, zahtevaju da Penelopa, Odisej i Telemah preuzmu odgovornost za njihovu smrt. One su svesne klasnog jaza zbog kog se nalaze u podređenom položaju:

I mi smo bile deca. I nas su rodili pogrešni roditelji. Roditelji siromasi, roditelji robovi, roditelji seljaci i roditelji kmetovi; roditelji koji su nas prodali, roditelji od kojih su nas ukrali. Ti roditelji nisu bili bogovi, nisu bili polubogobvi, nisu bili nimfe niti Najade. Dobile smo posao u palati, kao deca; težačile smo od jutra do sutra, kao deca. (Atvud, 2005: 25)

Uprkos tome, zahtevaju zadovoljenje pravde, pri čemu dolazi do modifikacije još jednog stilskog elementa - umesto plemićkih protagonista, niži slojevi društva koriste se apostrofom:

O, Ljutite, O Furije, vi ste nam poslednja nada! Preklinjemo vas da izvršite kaznu i iznudite osvetu u naše ime! Budite nam zaštitnice, nama, koje za života niko nije štitio! Nanjušite Odiseja, kud god išao! Iz mesta u mesto, iz života u život, kako god se prerušio, koji god oblik uzeo, saterajte ga u tesnac! Pratite ga u stopu, na zemlji ili u Hadu, gde god našao utočišta, u pesmama i dramama, u tomovima i tezama, u beleškama, na marginama i u dodacima! Prikažite mu se u našem obliku, našem uništenom liku, u obliku naših jadnih leševa! Neka zbog vas nikada nema spokoja! (Atvud, 2005: 132)

U skladu s tim, narativ sa sluškinjama simbolički ukazuje na „povratak potisnutog" i razotkriva tamnu stranu herojskih mitova koji sistematski oduzimaju glas diskriminisanim manjinama (Howells u Jung, 2014: 57). Dalje ukidanje hijerarhijskih podela ogleda se u načinu na koji Penelopa opisuje ulogu božanstava u životu smrtnika. Autoritet božanstava se u grčkim mitovima ne preispituje, ali u Penelopijadi dolazi do njihovog hijerarhijskog izjednačavanja: „Bogovi su po nekim groznim osobinama podsećali na derlad. [...] Bogovi i nisu uvek bili inteligentni u onoj meri u kojoj su želeli da nam se predstave“ (Atvud, 2005: 32-33, 42).

Etička opredeljenost junaka takođe nije toliko jasno iscrtana kao u antičkim mitovima. Penelopa je unutar muškog panteona opisana kao časna, uzorna i posluš- 
na, a Odisej nosi obeležja jungijanskog arhetipa „,heroja“ i „prevaranta“ (Vandamme, 2010: 34). Kroz ponovno ispisivanje mita, Atvud razotkriva mračnu stranu Odisejevog herojstva - vešanje sluškinja, sa kojim odbija da se suoči. Rodno obeležena figura „prevaranta“, tipično vezivana za muško božanstvo Hermesa, u Penelopijadi prenosi se na Penelopu i njene sluškinje. Za razliku od Odiseja, Penelopa prihvata moralnu zamagljenost: „Ima neke posebne draži u mogućnosti da u istom činu spojite poslušnost i neposlušnost" (Atvud, 2005: 91). Dok je u starogrčkoj drami Penelopa osuđena na epitet „verne ljube“, Atvud stvara prostor za lukavu, prevrtljivu Penelopu: „Nas dvoje smo bili - po vlastitom priznanju - izuzetno vešti i bestidni dugogodišnji lažovi. Pravo je čudo što smo poverovali u ono što nam je ono drugo ispričalo. Ali jesmo. Ili smo to rekli jedno drugom“ (Atvud, 2005: 125, 126). Atvud poriče jasnu polarizaciju između dobra i zla, negirajući postojanje jasno iscrtanih binarnih opozicija.

Uzimajući navedene izmene $u$ obzir, reinterpretacija u vidu stvaranja hibridnog teksta i poigravanja klasičnim motivima poziva na reviziju muškog kanona, pozajmljuje glas marginalizovanim figurama i osporava apsolutne istine i meta-sisteme.

\section{Tkanje kao nemi jezik}

Izazivajući falogocentričnu tradiciju koja oduzima glas ženskim subjektima, Elen Siksu uvodi termin l'ectriture feminine, odnosno, žensko pismo kao jezik koji: „će probijati pregrade, klasifikacije i retorike, recepte i kodove, [koji] uranja, prodire, oslobađa krajnje sačuvani diskurs, uključujući i onaj koji se smeje na pomen reči 'tišina', na onaj koji se ciljajući nemoguće, zaustavlja tik pred rečju 'nemoguće', i ispisuje je kao kraj“ (Siksu, 2010: 6). Siksu dalje iznosi manifest o funkcijama ženskog pisanja, od kojih je najbitnije ugraditi ženu u ,tekst, svet i u istoriju“ (Siksu, 2010: 1) kako bi se izazvao androcentrični jezik kao lokus represije.

Penelopino tkanje i paranje odvijaju se simultano na dva nivoa: bukvalnom i metaforičkom. Na figurativnom nivou, istaknuta je konceptualna metafora PRIČA JE TKANINA. Ovim tropom konkretna aktivnost tkanja izuzima se iz regularnog semantičkog niza i prenosi se u domen apstraktnog, u kom se tkanje izjednačava sa pripovedanjem, a tkanina sa pričom. U kontekstu grčke mitologije, konceptualni okvir tkanja vezuje se za figure poput suđaja i Arijadne. U prvom slučaju, niti predstavljaju krojenje ljudskih sudbina, dok se u drugom slučaju vezuju za bekstvo iz lavirinta, izlaz iz bezizlazne situacije pomoću mudrosti i promućurnosti. Obe funkcije prisutne su i u Penelopijadi. Kada Penelopa izrazi nameru da „isprede vlastitu nit“ (Atvud, 2005: 19) ona pretpostavlja priču kojom želi da iznese svoju stranu događaja, ali i pokušaj da i se izbavi iz neželjenog braka. Arahna je još jedna ličnost iz grčke mitologije koja se vezuje za veštinu tkanja i nepokornost pred akropoljskim božanstvima, zbog čega je pretvorena u pauka i osuđena da večno plete svoju mrežu. Ona se pominje i u Penelopijadi, a na jednom mestu sama Penelopa pravi paralelu između sebe i pauka:

Sam pokrov je gotovo istog trena postao legenda. „Penelopina mreža“, tako su ga zvali; tako se nazivao svaki posao koji bi na neki volšeban način 
ostao nedovršen. Nije mi se dopadao termin „mreža“. Ako je pokrov bio mreža, onda sam ja bila pauk. Ali nisam pokušavala da ulovim muškarce kao muve: baš naprotiv, prosto sam se trudila da se sama ne upetljam. (Atvud, 2005: 92)

Tkanje predstavlja nemi jezik kojim Penelopa tvori metis - lukavost koja se u mitosu uglavnom vezivala za muške heroje poput Odiseja. Unutar restriktivnog društvenog i lingvističkog sistema, žena je paradoksalno ,i sekundarna i originalna, i pasivna i aktivna, i nemi i govoreći znak“ (Bergren u Massoura, 2017: 397). Shodno tome, Penelopa postaje mitopoetski pesnik koji subverzivno dela iza kulisa, a njeno tkanje postaje metafora ateološkog stvaralačkog procesa. Njena mreža je: „,metaforičan govor, nema zamena za njen nedostatak verbalnog zanata [...] tkanje stvara značenje od neartikulisane materije, omogućava nemom materijalu da progovori“ (Bergren u Massoura, 2017: 398,9). Gilbert i Gubar objašnjavaju simboličku upotrebu predmeta kao što su razboj, konac, igle kao nemi jezik kojim žene uspevaju da se unutar oikosa odbrane od muške aproprijacije, ušivajući na taj način rane koje im je istorija nanela. Autorke takođe pominju pojam „rajske tapiserije” - magičnog mesta na kom žena prestaje da bude subverzivni pauk koji krišom plete svoju mrežu opskurnosti, već dobija priliku da sebe iskaže naglas (Gilbert/Gubar, 1984: 642). U paradigmi tkanje=metis=priča, niti tkanine postaju diskurzivne niti.

U Odiseji, Penelopi je jezik uskraćen, a cela njena suština sadržana je u Agamemnonovim rečima:

Srećan li si, dovitljiv Odiseju, sine Laertov, jer si dobio ljubu što veliku ima vrlinu? Kako je čestito srce Penelopa imala divna, ćerka Ikarijeva! Odiseja venčanog muža se sećala svagda! Potamneti nikada neće slava njene vrline, i bozi će umilnom pesmom med pozemljašima ljudma Penelopu proslavit' mudru. Kao Tindareju ćerka učinila nije zločinstva ubivši svojega muža; po svetu će strahotna pesma ovu opevat', i glas iza sebe ostavi ružan slabome ženskome rodu, ma bila neka i dobra. (Homer, 2004: 24.192-202)

Penelopa je podređena mitološkim formulama koje ističu patnju i pasivno trpljenje kao vrhunske ženske vrline, postavši tako arhetipska figura žene-anđela. Klitemnestra koja zajedno sa Egistom ubija Agamemnona nakon što je on prisili na brak i žrtvuje njihovu ćerku Ifigeniju data je kako bi se naglasile Penelopine vrline. Penelopa je svesna ovog sistema koji je ,zasnovan na apsolutističkoj binarnosti, u kojoj se jedan termin mora definisati tako što će negirati svoju suprotnost, sistem koji funkcioniše kroz potiskivanje razlika“"(Klejton, 2004: 40). Ona ga se takođe odriče kada kaže:

Zar nisam bila verna? Zar nisam čekala, i čekala, i čekala, uprkos iskušenju - gotovo porivu - da to ne činim? I na šta se ja svodim, nakon što je prihvaćena zvanična verzija? Na poučnu legendu. Na štap kojim tuku druge 
žene. Zašto da ne budu tako obzirne, tako dostojne poverenja, tako prožete patnjom kao ja? Oni su zauzeli takav stav, pevači, oni što raspredaju neverovatne priče. Ne sledite moj primer, želim da vam vrisnem na uvo - da, vama! Ali kada pokušam da vrisnem, zvučim kao sova. (Atvud, 2005: 18)

Penelopina naracija u kojoj tvrdi: „Ugrizla sam se za jezik. Čudo jedno da mi je i ostalo nešto od jezika, koliko sam ga često grizla tokom godina“ (Atvud, 2005: 118) može se povezati sa smernicama za prisvajanje muškog diskursa u Smehu Meduze (Le Rire de la Méduse): žena treba muški diskurs da „raznese, da ga obrne i ponovo prisvoji, da ga napravi njenim, razumevajući ga, preuzimajući ga u sopstvena usta, i da mu sopstvenim zubima pregrize jezik, da samoj sebi izmisli jezik sa kojim će u taj isti jezik prodreti“ (Siksu, 2010: 9). Koristeći metaforički nemi jezik tkanja, Penelopa uspeva da se oslobodi prostornih stega oikosa i izveze novu protivrečnu i prkosnu povest. Dok odbija prosce svojom lukavošću, Penelopa se ujedno bori i protiv neprijatelja koji je nevidljiv - protiv istorije koja dogmatizuje Odisejevu i Agamemnonovu verziju priče i jezika kao instrumenta koji joj to omogućava.

\section{Penelopijada kao metatekst}

Pored konceptualizacije tkanja kao nemog jezika kojim se istupa iz diskursa koji fetišizuje žensku patnju, javlja se još jedno moguće tumačenje po kom tkanje označava alegoriju celokupnog ženskog stvaralaštva. S obzirom na samoreferentnost teorijske građe u Penelopijadi i problematizovanje istorijskih narativa, ovaj roman se može sagledati kao raskrsnica gde se susreću metafiktivno i istoriografsko. Atvud se, čini se, makar i nesvesno, pridržava odrednica žanra istoriografske metafikcije koji „održava razliku između svog formalnog samopredstavljanja i svog istorijskog konteksta, i na taj način problematizuje samu mogućnost istorijskog znanja, jer tu ne postoji pomirenje, ne postoji dijalektika - postoji samo [...] neotklonjiva protivrečnost“ (Hačion, 2014: 183). U ovom romanu, ona na dva plana - intradijegetičkom i ekstradijegetičkom osporava istinu istorijskog zapisa. Na prvom, ona rekonstruiše Penelopin lik koji je kroz istoriju predstavljao eksponent svih stereotipnih predstava žena poteklih iz pera muških pisaca. Na širem planu, ona se suprotstavlja tvrdnjama o autonomiji i superiornosti muških književnih preteča i demarginalizuje ulogu ženskih stvaralaca.

Naime, kreativno ustručavanje pred monumentalnom, autoritarnom figurom muškog pisca može dovesti do anksioznosti ženskog autorstva. Književnice sagledaju pisanje kao primarno androcentričnu sferu u kojoj ne uspevaju da se identifikuju sa muškom pretečom, što doprinosi osećaju neadekvatnosti. Isto tako, Siksu će se dotaći muškog pisanja kao mehanizma za potiskivanje ženskih glasova. Žensko ustupanje pred činom pisanja ona vidi kao proisteklo iz društveno usađenih ubeđenja: „Pismo je previše visoko i previše veliko za tebe, ono je rezervisano za velike, što će reći za 'za velike muškarce'; a to je glupost“ (Siksu, 2010: 2). Umesto anksioznosti, ona ovo negativno usmerenje ka sebi i sopstvenom talentu vidi kao anti-narcizam i anti-ljubav, te se ukidanje transistorijskih kodova može tumačiti i kao potraga za 
sopstvom, ljubavlju prema sebi i osećaju sopstvene vrednosti. Tekstovi kao što je Penelopijada kreiranjem pandana muškim tekstovima i fokalizacijom ženskih perspektiva otvaraju prostor za alternativno tumačenje mita i procvat ženskog stvaralačkog principa. Zaključak je, dakle, da književnice kroz svoju angažovanost u revizionarskoj prozi mogu ne samo da isprave nepravde počinjene u prošlosti već $i$ da ostave komentar o svom autorstvu.

Za Džasmin Ričards, Penelopino tkanje predstavlja neoboriv dokaz da Atvud odbacuje restriktivno načelo autorske anksioznosti. U Odiseji, njena lukavost kojom uspešno odvraća prosce pripisuje se boginji Ateni. Atvud stoga koristi Atenu kao simbol preteče Autora/boga koji potire kreativnu autonomiju ženskog autora (Richards, 2019: 135). Antinoj, pripisujući Penelopin talenat isključivo Ateni, na jednom mestu u Odiseji izjavljuje:

Ako li ahejske ljude i odsad kinjila bude onom vična u duši što joj dade Atena, prelepa dela da zna, i jakim obdari je umom i još kovarstvom kakvo od negdašnjih takvih Ahejki nijedna imala nije. (Odiseja, 2004: 2.116-19)

Penelopa odlučno odbija ovakvu verziju događaja:

Kada sam kasnije pričala tu priču, govorila sam da mi je Palada Atena, boginja tkanja, dala ideju, i, što se mene tiče, možda je i bilo tako; no, pripisivanje vlastitih nadahnuća nekom bogu uvek je bio dobar način da izbegnete optužbe za gordost ukoliko zamisao uspe, kao i krivicu ukoliko propadne. [...] U pesmama se kaže da ništa nisam primetila zato što mi je Atena odvratila pažnju. Ako u to verujete, onda ćete poverovati u svaku glupost. (Atvud, 2005: 88, 106)

Pored odbacivanja ženske autoritativne figure, Atvud će, odana tezi da apsolutna istina ne postoji, izjednačiti muško i žensko stvaralaštvo stavljajući Odiseja i Penelopu u istu ravan nepouzdanog autora kao „vešte i bestidne lažove“. Dok je u Odisejeve priče uvrežena pretpostavka istinitosti, Penelopa potencira nepouzdanost svog stvaralaštva. Činjenica da se Odisejeva verzija događaja uzima kao jedina istinita može se okarakterisati kao kritika inherentnog učitavanja autoriteta i epistemološke autentičnosti u muške mitove. Penelopa kao intradijegetička predstava figure ženskog stvaraoca izaziva ovo tumačenje.

Gilbert i Gubar (1984) postuliraju sličnu vrstu anksioznosti koja se javlja pod uticajem patrijarhalne književne etiologije i manifestuje se kao verovanje da je muški autor neprikosnoveni estetski autoritet. U Penelopijadi, hor sluškinja će „koplje“ i „reč“ (Atvud, 2010: 8) kao metonimije muškosti staviti u istu ravan kada se radi o njihovom razaračkom potencijalu. Na sličan način, predlaže se ideja smrti koja proističe iz tekstualne kolonizacije ženskog tela. Paradoks se krije u činjenici da muški autor $u$ isti mah izrađa i zarobljava svoje likove, udiše im život kako bi im oduzeo sposobnost nezavisnog govora. Okamenivši ih zauvek u večnosti svoje umet- 
ničke građe, on ih ubija. Olovka, dakle, jeste podjednako pogubna. Alternativa koja se daje ovakvoj vrsti duhovne smrti je sledeća: žene moraju pobeći iz muških tekstova koji im uskraćuju slobodu kako bi se suprotstavile autoritetu koji ih je zatočio i sprečio da se prihvate olovke. One moraju strgnuti mitološke maske koje su im navukli muški pisci u pokušaju da ih poseduju i svedu na tipske odrednice kao što su „anđeo“ ili „,̌udovište“ (Gilbert/Gubar, 1984: 16). Književnice se moraju drznuti da, poput Penelope, preuzmu kontrolu nad dominantnim narativom, i sa margina istorije ispišu priče o ženskim likovima koji ujedno predstavljaju odraze njih samih.

\section{Zaključak}

Penelopijada putevima parodijske intertekstualnosti $\mathrm{i}$ istoriografske metafikcije uspeva da dokaže da epoha zasićenosti još uvek nije nastupila i da je postmodernizam prvenstveno epoha „književnosti obnavljanja“. Interakcija sa prošlošću prikazana je kao plodotvorna kada se radi o pozajmljivanju konvencija koje treba preispitati i modifikovati. Treba imati na umu da se iz te spone sa istorijskim pretečama bez izuzetka rađa kritički nastrojeno delo: „to je uvek kritička prerada, nikad nostalgičan povratak“ (Hačion, 1996: 18). Postmodernizam prisvaja isključivo da bi rušio. U tom smislu, možemo preuzeti Bartov model „trećeg semiološkog lanca“ kako bismo predložili održivu alternativu u vidu različitih ,-ijada“ koje bi pridružile nove kulturološke konotacije postojećim mitološkim pretpostavkama.

Sagledan iz feminističke perspektive, roman prebacuje težište sa muškog logocentrizma i podriva rodne stereotipe, kako one vezane za žensku ulogu unutar društvenog konteksta, tako one vezane za njihovu ulogu u stvaralačkoj umetnosti. Neimenovane, subalterne figure postaju protagonisti sa silovitim, gromoglasnim prisustvom koje izaziva rodno i klasno zasnovanu marginalizaciju. Penelopa je odenuta novim predstavama ženstvenosti koja se ne svodi na poslušnost, stalnost, trpeljivost i ćutljivost, već može postojati u moralno ambivalentnom prostoru. Uz to, Penelopino tkanje postaje simbol književnog stvaranja, i šire, ženske emancipacije - vezući sopstvenu mrežu, ona istovremeno razvezuje mreže moći u kojima je zarobljena.

Sintetišući Penelopino pripovedanje sa univerzalnijim idejama o ženskom pisanju, Atvud prenebregava granice koje razdvajaju lično od kolektivnog. Poput Penelope, i savremene žene suočavaju se sa vrednosnim sistemom koji tvrdi da žene nisu dostojne velikih podviga - herojskih ili književnih. Prekrajanjem tradicionalnih narativa koji pretpostavljaju monopol na reč izaziva se status quo i potencira se otvorenost kanona za nova tumačenja i revizije.

\section{Literatura}

Atvud, M. (2005). Penelopijada. Beograd: Geopoetika.

Bart, R. (2013). Mit danas. U Mitologije (O. Petronić, prev.) (str. 183-227). Novi Sad: Karpos.

Clayton, B. (2004). A Penelopian Poetics: Reweaving the Feminine in Homer's Odyssey.

Lanham: Lexington Books. 
Gilbert, M. S., Gubar. S. (1984). The Madwoman in the Attic: The Woman Writer and the Nineteenth-Century Literary Imagination. New Haven: Yale University Press.

Hačion, L. (1996). Poetika postmodernizma (V. Gvozden i Lj. Stanković, prev.). Novi Sad: Svetovi.

Homer. (2004). Odiseja (M. N. Đurić, prev.). Beograd: Dereta.

Howells, C. A. (2008). Five Ways of Looking at The Penelopiad. Sydney Studies in English, 32, 5-18.

Jung, S. (2014). 'A Chorus Line': Margaret Atwood's Penelopiad at the Crossroads of Narrative, Poetic and Dramatic Genres. Connotations: A Journal for Critical Debate, 24 (1), 41-62.

Korkmaz, F. T. (2010). Rewriting Myths: Voicing Female Experience in Margaret Atwood's Surfacing and The Penelopiad and Marina Warner's Indigo and The Leto Bundle (unpublished doctoral dissertation). Middle East Technical University, Ankara.

Kristeva, J. (1984). Revolution in Poetic Language (M. Waller, Trans.). New York: Columbia University Press.

Kristeva, J. (1986). Word, Dialogue and Novel (A. Jardine, T. Gora \& L. S. Roudiez, Trans.). In T. Moi (Ed.), Kristeva Reader (pp. 34-61). New York: Columbia UP.

Lisowska, K. (2014). Women and Intertextuality: On the Example of Margaret Atwood's The Penelopiad. Analyses/Rereadings/Theories Journal, 2(1), 18-27.

Massoura, K. (2017). Space, Time, and the Female Body: Homer's Penelope in Margaret Atwood's The Penelopiad. Contemporary Women's Writing, 11(3), 391-411.

Richards, J. (2019). The Anxieties of Female Authorship in Margaret Atwood's The Penelopiad. In F. Cox \& E. Theodorakopulos (Eds.), Homer's Daughters: Women's Response to Homer in the Twentieth Century and Beyond (pp. 125-141). Oxford: Oxford University Press.

Siksu, E. (2010). Smeh Meduze (S. Milutinović-Bojanić, prev.). ARS, 5.6. http://www. scribd.com/doc/122338258/Helene-Cixous-Smijeh-meduze-Elen-Siksu-Smehmeduze\#scribd

Suzuki, M. (2007). Rewriting the Odyssey in the Twenty First Century: Mary Zimmerman's Odyssey and Margaret Atwood's Penelopiad. College Literature, 34(2), 263-278.

Vandamme, J. (2010). "Strong myths never die". The Rewriting of the Penelope Myth in Margaret Atwood's The Penelopiad (Unpublished manuscript). Gent: Universiteit Gent. 


\section{Marija N. Gagić}

\section{Summary}

\section{I'LL SPIN A THREAD OF MY OWN: PREFIGURATION OF THE FAITHFUL PENELOPE MYTH}

In her novel The Penelopiad Margaret Atwood deconstructs patriarchal practices rooted in Homer's The Odyssey by using and abusing mythological conventions. Bearing that in mind, this novel can be described as representative of the postmodernist parodic dialogue with the past. The framework for the study of post-Homeric modifications can be found primarily in intertextual, structuralist, metafictional and feminist perspectives. Androcentric attitudes featured in the original myth are reinvented through intertextual practices and semiological redistribution. In addition to that, the plurality of narrative perspectives becomes gender-marked, as a female tactic for revising phallogocentric systems. Passivity and suffering cease to be Penelope's main traits, due to her actively resisting her own victimization. Her maids, previously silent and marginalized figures, are given an opportunity to demand justice from a hierarchically equal position. The paper offers an additional perspective - historiographic metafiction, according to which Penelope's weaving represents the symbol of female authorship as a whole, thus inviting female writers to actively contribute to the literary canon.

\section{Key words:}

prefiguration of myths, The Odyssey, Penelope, intertextuality, feminist theory, metafiction 